\title{
REALM project releases results from latest tests of coronavirus on leather, summary of research
}

https://doi.org/10.1515/bd-2021-0006

The REALM project has released results from the latest round of scientific tests to determine how long the SARS-CoV-2 virus that causes COVID-19 can remain on materials found in archives, libraries and museums, along with a summary of published research to help inform these institutions as they reopen to the public.

"Those who handle special collections or vintage books and materials may find the testing from this round of particular interest," said Scott Carey, Chief Information Officer at IMLS and Deputy Director of the Office of Digital and Information Strategy. "The sample tested was an antique leather book cover, which mimics a scenario where standard cleaning methods may be undesirable. The variability of how long the virus lasts on materials reinforces the continued importance of practicing good hygiene, following local health officials' guidance, and making informed, risk-based decisions."

New lab test findings from Battelle show that the infectious virus survived through eight days on both natural leather and synthetic leather fabrics. (See Test 5 results.)

"Battelle's testing provides a real-world approach using substances such as synthetic saliva to determine how long the SARS-CoV-2 virus persists on materials relevant to libraries, archives and museums," said Will Richter, Principal Research Scientist at Battelle and a leader of the research being done for the REALM project. "In the latest round of testing, we used a leather book binding from the 1860s that was held in a library system. We continue to adjust the selected timepoints in an attempt to capture the full decay profile of the virus. We will steadfastly follow the science as we proceed with testing these materials.”

The project also made available a compilation of SARS-CoV-2 scientific research published through mid-August 2020, which summarizes current research on how the virus spreads, its survival on materials and surfaces, and the effectiveness of various prevention and decontamination measures. The new research review highlights growing evidence that direct contact and respiratory droplets appear to be the primary modes of spread, and that aerosols may be a contributor to infection.

"The expert review of published research is an essential component of this project," said Lorcan Dempsey, Vice President, OCLC Membership and Research, 
and Chief Strategist. "This analysis provides important contextual background, showing what we actually know and still don't know about the coronavirus. These reviews, alongside the testing of the virus' persistence on the materials, will continue to be a resource for libraries, archives and museums, helping them plan with confidence as they put in place frameworks to help protect their staffs and communities."

The summary of relevant research also underscores the fact that there remain some critical "known unknowns" about the COVID-19 virus, including how much virus is needed to infect someone, how much virus an infected person sheds, and whether people are getting infected by touching objects and surfaces. (Read the research summary.)

The REopening Archives, Libraries, and Museums (REALM) project is designed to generate scientific information to support the handling of core library, museum, and archival materials as these institutions begin to resume operations and reopen to the public. The project is supported by the Institute of Museum and Library Services (IMLS), the primary source of federal funding for museums and libraries; and OCLC, a nonprofit library technology and research organization; in partnership with Battelle, a not-for-profit global scientific research and development organization.

Project updates are posted at oc.lc/realm-project as they become available. Those interested can also sign up through the project website to receive timely email updates when new information is released.

\section{About the Institute of Museum and Library Services}

The Institute of Museum and Library Services is the primary source of federal support for the nation's libraries and museums. We advance, support, and empower America's museums, libraries, and related organizations through grantmaking, research, and policy development. Our vision is a nation where museums and libraries work together to transform the lives of individuals and communities. To learn more, visit www.imls.gov and follow us on Facebook and Twitter.

\section{About Battelle}

Every day, the people of Battelle apply science and technology to solving what matters most. At major technology centers and national laboratories around the world, Battelle conducts research and development, designs and manufactures products, and delivers critical services for government and commercial customers. Headquartered in Columbus, Ohio since its founding in 1929, Battelle serves the national security, health and life sciences, and energy and environmental industries. For more information, visit www.battelle.org. 


\begin{abstract}
About OCLC
OCLC is a nonprofit global library cooperative providing shared technology services, original research and community programs so that libraries can better fuel learning, research and innovation. Through OCLC, member libraries cooperatively produce and maintain WorldCat, the most comprehensive global network of data about library collections and services. Libraries gain efficiencies through OCLC's WorldShare, a complete set of library management applications and services built on an open, cloud-based platform. It is through collaboration and sharing of the world's collected knowledge that libraries can help people find answers they need to solve problems. Together as OCLC, member libraries, staff and partners make breakthroughs possible.
\end{abstract}

\title{
Further Information:
}

- REALM project: https://www.oclc.org/realm/home.html

- Test 5 results: https://www.oclc.org/realm/research.html\#test5

- Research Summary: https://www.oclc.org/realm/research/phase-2-systema tic-literature-review.html

- Sign up to receive REALM project updates by email: https://www.oclc.org/ realm/subscribe.html

- Institute of Museum and Library Services on Facebook: https://www.face book.com/USIMLS

- Institute of Museum and Library Services on Twitter: https://twitter.com/ us_imls

- Batelle: https://www.battelle.org

- OCLC: https://www.oclc.org/de/home.html?redirect=true

- WorldCat: https://www.oclc.org/en/worldcat.html

- WorldShare: https://www.oclc.org/en/worldshare.html

\section{Bei Rückfragen:}

OCLC GmbH, Gabriele Wolberg

Tel.: + 49 (0) 89 61308-326 | E-Mail: Gabriele.Wolberg@oclc.org

URL: http://www.oclc.org | Twitter: @OCLC_DE 